\title{
PLOJDY ANALYSIS AND DNA CONTENT OF MUTANT BANANA "PISANG BERANGAN" USING FLOW CYTOMETRY
}

\author{
ABDELGADIRRAYIS SHADIA, ROFINA YASMINOTHMANand MAKCHAI \\ Division of Genetics and Molecular Biology, Institute of Biological Sciences, \\ Faculty of Science, University of Malaya, Kuala Lumpur, Malaysia
}

\begin{abstract}
Mutagens cause random changes in the nuclear DNA or cytoplasmic organelles, resulting in gene, chromosomal or genomic mutations and hence, create variability. In this study, flow cytometry (FCM) was used to determine ploidy levels and DNA content in gamma-irradiated variants of mutated Pisang Berangan (cv. Intan, AAA) - a local banana genotype. Induced variants such as short plant stature (stunted growth), late flowering plants (late maturity) and abnormalities in bunch characters were selected to study possible changes at the DNA level. The study showed that DNA content of mutated plants differed from non-irradiated control and that irradiation had the most effect at high doses (40 and $60 \mathrm{~Gy}$ ). The increase of DNA content in $20 \mathrm{~Gy}$ and $30 \mathrm{~Gy}$ treated plants was not more than that of the control plants. The values of genomic DNA content of gamma-irradiation variants decreased as the dose of irradiation increased from 20 to $60 \mathrm{~Gy}$, indicating that the high dose of gamma-irradiation had a significant effect on the genome of the plants.

The analysis further showed that phenotypic variation due to mutagenesis was reflected in the DNA content of the plants. The results also showed that ploidy levels were not affected by gamma-irradiation even at high doses.
\end{abstract}

Keywords: Musa spp/mutation breeding/ flow cytometry/ploidy level/ DNA content

\section{INTRODUCTION}

Banana is the most important fruit crop in the world (Kaemmer et al. 1997). It forms the primary food source for millions of people in many parts of the world and ranks next to rice and wheat (INIBAP 1992). The cultivated bananas are mostly triploid $(2 n=3 x=33)$ and exhibit a marked degree of sterility. Sterility is a main problem of banana breeding, which is very complex depending on meiotic irregularities (Novak 1992). Therefore, genetic improvement has been difficult due to lack of useful genetic variability and low level of female fertility. Hence, the potential of biotechnological techniques to complement conventional Musa breeding has been widely investigated (Wiame et al. 2000; Vuylsteke 1998; Ortiz \& Vuylsteke 1996). These techniques involved in vitro multiplication, mutation breeding and genetic manipulation.

Popular clones planted in Malaysia on a commercial scale are mainly Cavendish bananas and Pisang Berangan cv. Intan (AAA) (Mak et al. 1995). Of the total cultivated areas almost half are cultivated with Pisang Berangan and the Cavendish types for both local consumption and export (Siti Hawa 1998). Pisang Berangan has good fruit quality, colour, texture, size and shelf-life, in addition to its ease of ripening without cold treatment. The plants are however, relatively tall with mode- 
rate yield and are very susceptible to a number of diseases particularly Fusarium wilt caused by Fusarium oxysporum f. sp. cubense. Pisang Berangan is a sterile tri-ploid banana; therefore, complementary techniques such as tissue culture and mutagenesis are of great potential. Induced mutation in bananas is an attractive means to generate genetic variability.

Mutation induction coupled with in vitro techniques induces morphological changes and also increases variability in quantitative traits. Physical mutagens, such as gamma ray, are tools for enhancing and generating genetic variations by inducing mutations at the gene, chromosome and genome level, in nuclear and cytoplasmic organelle DNA (Larkin 1998). Somaclonal variation provides additional source of variation. Off-types have been noted for plant stature (mainly dwarf), leaf foliage, pseudostem and bunch characters (small bunches, short fingers, long peduncle and elongated male buds).

The DNA nuclear content of various banana varieties were not explored or determined until the use of flow cytometry method for plant was introduced in the early 1980s. Flow cytometric analysis of nuclear DNA content provides an alternative for individual and largescale ploidy screening (Dolezel 1991). The technique first developed for analysis of human cells has been adopted as a convenient tool for estimation of nuclear DNA content and ploidy level constitutions in plants (Dolezel 1991; Dolezel et al. 1994; Dolezel et al. 1997). Dolezel et al. (1994) modified the technique for analysis of nuclear genome of bananas and plantains. The method that was used to screen ploidy levels of plants regenerated from in vitro culture was also used to estimate genome size and its variation in Musa.

This paper presents the results of a study to evaluate the variability in Pisang Berangan cv. Intan (AAA) generated by gamma irradiation in terms of changes in nuclear DNA content and chromosome level by flow cytometric analysis.

\section{MATERIALS AND METHODS}

Vigorous and disease-free suckers of Pisang Berangan (AAA) were selected from fieldgrown, true-to-type, fruit-bearing mother plants. Shoot tip meristem (approximately $5 \times 5 \times 5$ $\mathrm{mm}$ ) was removed with a sterilized scalpel, then transferred directly to modified MS medium. Subculturing was carried out after 4-6 weeks or earlier depending on blackening of explants. Shoots initials developed after 3 weeks and were proliferated on induction medium with the BAP concentration of $4.5 \mathrm{mg} / \mathrm{L}$. Multiplication of propagules was carried out by subdividing the newly formed shoots or bud clusters and reculturing them on fresh medium at 4-6 week intervals up to sub-culture 6. MS medium was then supplemented with $2 \mathrm{mg} / \mathrm{L} 1 \mathrm{AA}$ and $5 \mathrm{mg} / \mathrm{L}$ kinetin for rooting. Root generation took 6-8 weeks until plantlets reached the optimal size of $4-5 \mathrm{~cm}$.

The shoot-tip meristem pieces (about $1 \mathrm{~cm} \mathrm{x} 2 \mathrm{~mm}$ ) were aseptically excised from micropropagated plantlets of Pisang Berangan. Each shoot-tip was cut longitudinally into two pieces and then transferred to sterile moist Petri dishes. Each 
Petri dish contained 10 meristem pieces and was sealed with parafilm. Gamma induction was then carried out at the Malaysian Institute of Nuclear Technology Research (MINT). The meristem pieces were irradiated in a gamma cell with a Cobalt-60 $\left({ }^{60} \mathrm{Co}\right)$ source (GC 400A, $10 \mathrm{Kci}$ ). The doses included 0 (control), 20, 30, 40 \& $60 \mathrm{~Gy}$ at a dose rate of 0.54 Gy/sec. The irradiated meristem pieces were washed thoroughly with sterile distilled water and cultured on modified MS solid medium (Ho \& Tan 1990). Sub-culturing was carried out at 4 - 6 week intervals until generation $\mathrm{M} \mid \mathrm{V}_{4}$ i.e. three sub-cultures. The explants after $\mathrm{MiVj}$ were allowed to root in rooting medium containing MS salts. After three to four weeks in rooting medium, the plantlets were deflasked and transplanted in the nursery for acclimatization or hardening (8-9 weeks). The plantlets were maintained under $70 \%-80 \%$ shade (using shading net) and high humidity. These materials were generated for field evaluation at the farm. The plants were grown in rows spaced at $2.5 \mathrm{~m} \times 2.5 \mathrm{~m}$ in a triangular pattern with completely randomized design. Abnormal and mutant plants identified from different gamma-dose treatments (20, 30, 40, and $60 \mathrm{~Gy}$ ) were selected from in vitro plantlets, glass house-grown and field-grown plants.

\section{Plant Materials and Sample Preparation}

For determination of ploidy level and identification of nuclear DNA content by FCM, nuclei were isolated from young leaves following the method developed by Gailbraith et al. (1983). Approximately 40 - $50 \mathrm{mg}$ of young leaves from each sample (mutated \& Glycine max var. Palmetto) were chopped up together with a sharp scalpel blade in a glass Petri dish containing $1 \mathrm{ml}$ LBOI lysis (Dolezel 1991), supplemented with $50 \mathrm{ug} / \mathrm{ml}$ each of Propidium-iodide (PI) and RNAse. Glycine max was used as internal reference standard for identifying the nuclear DNA content by FCM. An intact interphase nucleus was released from the cut surface directly into 2-ml lysis buffer supplemented with $0.1 \mathrm{mg} / \mathrm{ml}$ of 4,6-Diamidino-2-phenylindole (DAPI). The homogenate-stained nuclei were filtered through 50 jam nylon mesh into the analysis tube and its fluorescence was analyzed by FCM.

\section{Instrument setting and alignment}

The fluorescence intensity of DAPI-stained nuclei was measured using a Partec CA11 flow cytometer (Partec GmbH, Munster, Germany), that uses high-pressure mercury arc lamp (HBOOOW/2L), as an excitation light source. These were filtered through a combination of optical filters: KGI, BG38 and UGI for excitation: TK560 as dichronic mirror, and a long-pass emission filter of RG590. Autoclaved deionized water was used as a sheath fluid.

\section{Sample analysis}

About $2 \mathrm{ml}$ of the homogenate nuclei was analyzed in the Cell Counter Analyzer Cytometer (Model Partec CCA-II). The fluorescence was measured with a $100 \mathrm{~W}$ high-pressure mercury arc lamp as a light source filtered as mentioned above. 
The DNA genome size of the sample was then estimated using the ratio of Gl peaks. The nuclear DNA content was quantified by the following formula

\author{
2C nuclear DNA content fpg] = 2.5/fluorescence ratio* \\ * Fluorescence ratio = Peak mean of Musa \\ of Glycine max \\ Peak mean
}

Symbol C is used for DNA content of haploid set of chromosomes. Glycine max has 2C DNA content $=2.5 \mathrm{pg}$ (Tiersch et al. 1989).

\title{
RESULTS AND DISCUSSION
}

Mutagenic treatment may cause histogenic disturbances. At the molecular level, mutagens cause random changes in the nuclear DNA or cytoplasmic organelles, resulting in gene, chromosomal or genomic mutations that create variability. The changes may be a result of alterations of the DNA sequence of gene such as gain, loss or substitution of one base pair by another. Therefore, monitoring of mutagen-induced DNA damage is potentially very useful in mutation breeding studies.

In this study, mutation induction was used to generate variability in Pisang Berangan (AAA). At high doses of irradiation, too many mutational events per cell may be induced, with increased risk that a favourable mutation is accompanied by one or more unfavourable genetic changes. However, in vegetatively propagated crops (bananas) it is impossible to separate favourable from unfavourable mutations by cross-breeding mutants among each other or by back-crossing with the original material. Therefore, the evaluation of mutants is very difficult unless alternative techniques such as analysis of DNA content or molecular fingerprinting are used. To a certain extent, the evaluation of mutants can also be phenotypically possible depending upon certain characteristics when compared with control plants.

Flow cytometry (FCM) was used in this study to determine ploidy levels and DNA content in gamma-irradiated (Pisang Berangan) variants. The variants chosen for DNA analysis include those with short plant stature (stunted growth), late flowering (or late in maturity) and abnormal bunch characteristic (Table 1). The selection of short stature plants was based on two main categories, severely stunted and weak (plant height were $<75 \mathrm{~cm}$ ) and short plants measuring 150-170 cm. While the selection of lateness in flowering was compared with control plants. The late flowering types ranged from 380 to 465 days. Some plants showed more than one variant character such as short plants that were also late in maturity or even failed to bunching. The number of variants with bunch and finger abnormalities recorded was few and included those with short compressed bunch with few hands or combs $(<4)$, bunch with long peduncle and abundant persistent flowers at the distal end of the bunch stalk, bunch with male flowers only or bunch with gaps (missing combs), fused fingers and long and thin fingers. 
Ploidy analysis and DNA content of banana mutant - Abdelgadir Rayis Shadia et at.

Table 1. Samples of different variants induced by gamma-irradiation selected for ploidy analysis and DNA content

\begin{tabular}{lccccc}
\hline \hline \multirow{2}{*}{ Types of Variants } & \multicolumn{5}{c}{ Number of plants (\%) } \\
\cline { 2 - 6 } & $20 \mathrm{~Gy}$ & $30 \mathrm{~Gy}$ & $40 \mathrm{~Gy}$ & $60 \mathrm{~Gy}$ & Control \\
\hline - Dwarf \& stunted growth & $19(38 \%)$ & $17(34 \%)$ & $30(60 \%)$ & $34(68 \%)$ & - \\
- Late flowering & $15(30 \%)$ & $18(36 \%)$ & $11(22 \%)$ & $10(20 \%)$ & - \\
$\begin{array}{l}\text { Abnormal bunch } \\
\text { characteristics }\end{array}$ & $16(32 \%)$ & $15(30 \%)$ & $9(18 \%)$ & $6(12 \%)$ & 50 \\
\hline Total & 50 & 50 & 50 & 50 & 50 \\
\hline
\end{tabular}

Flow cytometric analysis for ploidy and DNA content

The most reliable conventional method of ploidy level analysis is the counting of chromosomes of metaphase plates by using root tips. However, the preparation and microscopic analysis is time consuming, and a difficult task as banana chromosomes are extremely small, indistinguishable and frequently few cell divisions are visible in a single root tip. This has led to the development of flow cytometric techniques for rapid routine ploidy determination in Musa (Dolezel et al. 1994). In addition, flow cytometry is recommended for the accurate estimation of nuclear DNA content (Novak 1992; Dolezel et al. 1989). Flow cytometry involves the analysis of intact nuclei, hence dividing cells are not required, and the analysis is not limited to meristematic tissues. Moreover, a small amount of fresh leaf tissue (5 $50 \mathrm{mg}$ ) is sufficient, that means this method could be applied to plants at the early stage of development.

Analysis of the relative fluorescent intensity of propidium-iodide stained nuclei yielded a histogram showing two dominant peaks corresponding to $G \backslash$ and $G_{2}$ nuclei of Pisang Berangan and Glycine max cv. Palmetto, respectively. The majority of cells in full-grown plants does not participate in cell division and reside in a so-called GO ( $G$ is gap) stage of the cell cycle. At this stage, the nuclear DNA content reflect the ploidy state of the plant. Cells, which are involved in divisions, start from a comparable so-called GI state and subsequently pass through $\mathrm{S}$ (= DNA-synthesis), $\mathrm{G}_{2}$ (= an interphase nuclear stage with a doubled DNA content preceding the actual nuclear division). Accordingly nuclear DNA content in absolute units (genome size in picogram-pg DNA) was adopted for all samples used. Such estimation requires comparison with a reference standard having a known DNA content. In this study, Glycine max was used as an internal standard because its genome size is relatively constant (Dolezel et al. 1994, Vinderlov et al. 1983) and to avoid bias due to staining and instrumental changes when estimating nuclear DNA 
ploidy by flow cytometric analysis. The precision of the ratio between the standard and the sample (Pisang Berangan) reflects the accuracy of DNA content measurements.

Estimation of ploidy level was done by external standardization procedure comparing the position of the $G$ | peak on a histogram to that of a reference plant with known ploidy. The results showed no significant differences in ploidy level between all samples used (3n), indicating that irradiation at the. doses used did not have an effect on ploidy. Differences were, however, found between gamma-irradiated Berangan variants with respect to DNA content. Dolezel (1995) reported similar findings in his analysis of a large populations of nuclei (5-2000) of mutated African plantains in which the occurrence of even small subpopulations differing in ploidy levels (mixoploidy) can be detected. The applications envisaged include control of ploidy level stability and screening for novel ploidy levels.

Figure (1) shows flow cytometric analysis of genomic DNA content of Pisang Berangan nuclei and from the reference (Glycine max $c v$. palmetto) stained with propidium iodide (PI). The nuclei isolated from Musa and Glycine, were analyzed simultaneously. Most of the nuclei were in G, phase of the cell cycle. The first peak (Channel 75) represented G, nuclei of Musa, while the second peak represented G, nuclei of Glycine. G, peak of Pisang Berangan was positioned on channel 75, and the other peak of Glycine max was on channel 100. A third peak also appeared at channel 200 reflecting the $G_{2}$ phase of the reference internal standard nuclei.

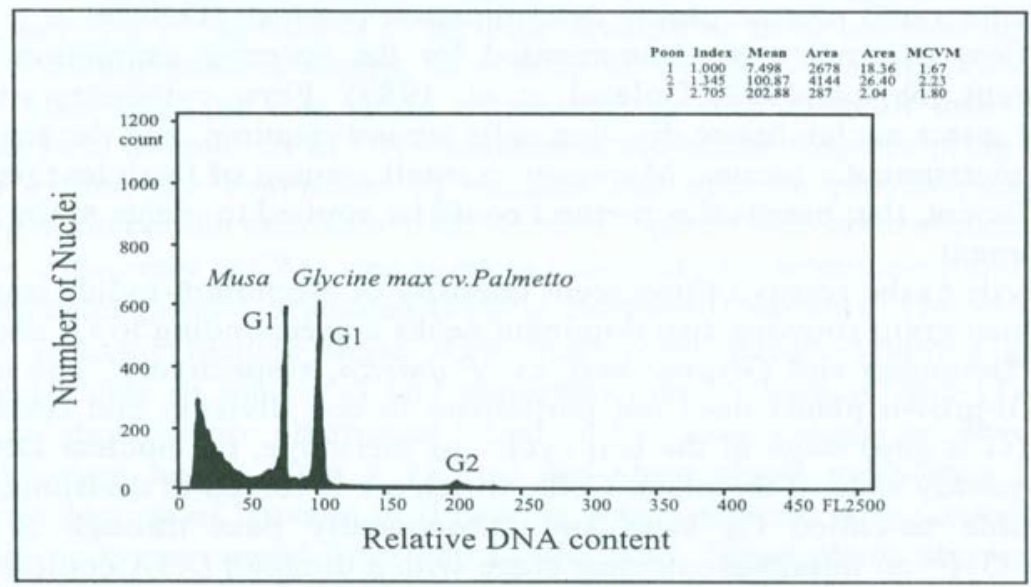

Figure 1. Histogram of relative nuclear DNA content. Genomic DNA contents were obtained after simultaneous analysis of Musa cv.Berangan (AAA) and Glycine max cv.Palmetto. Two peaks were obtained for Glycine max i.e. G1 and G2 compared to only one observed in Musa (Berangan) at channel 75. The nuclei were stained with propidium iodide. The relative DNA contents for Musa (Berangan) were determined from the ratios of the G1 peaks of the reference standard and the samples. 
A measurement for the resolution of the histograms- Coefficient of variation (CV)- shows the variation of the analysis from the control values. Overall means of G] peaks of Pisang Berangan ranged from $1.3 \%$ to $2.34 \%$, whereas in Glycine plants, it ranged from $1.02 \%$ to $1.67 \%$. The estimated values of peak ratio of these samples could be used to discriminate between gamma-irradiated variants and non-irradiated plants. The peak appeared in the histogram, G[ for Pisang Berangan and G| for Glycine max, indicated that soybean has more DNA content than Berangan. Higher CV in Berangan indicated that variation due to mutagenesis occurred within these samples. The discrepancies between observed and expected values could indicate the occurrence of changes in DNA content due to effects of gammairradiation. All selected variants (short stature, late flowering and bunch abnormalities) showed DNA content different from control plants. To investigate the significance of differences between observed frequencies arranged in these three characters the use of contingency $x^{2}$-test for independence was performed. The test showed that there is a differential effect of gamma irradiation on these characters, but the two sets of variables are independently acting.

\section{DNA content of different types of variants induced by gamma-irradiation (mutants)}

All selected mutants (short stature, late flowering and bunch characteristics) showed variation in DNA content. An effect of irradiation appears to be reflected by an increase in variation of nuclear DNA content (increase of coefficient of variation of $G$ and $G_{2}$ peaks). The mean of the distribution of $\mathrm{G}_{0} / \mathrm{G}$, nuclei represents a $2 \mathrm{C}$ (presynthetic level) DNA amount in relative units. The ratio of $\mathrm{G}_{0} / \mathrm{G}$, peak means (Musal Glycine) was calculated and DNA content of Musa was estimated according to the formula:

DNA content $(\mathrm{Pg})=2.5 /$ peak ratio (Dolezel et al. 1994).

The ratio of Gl peak means for non-irradiated control plants was GI of Glycine/ G, of Musa i.e. $100 / 75=1.333$. The 2C DNA content of Pisang Berangan (AAA) was calculated using the ratio of Gl peak means: 2.5/1.333=1.875 pg DNA or $1.875 \pm 0.02 \mathrm{pg}$. The estimated value of peak ratio of these plants did not differ from the mean value obtained by FCM analysis (1.85 pg).

The estimated value of DNA content (pg \& Mbp) for different variants chosen from each group is shown in Table 2. Short plant variants (gamma-irradiated at different doses) displayed a wide range of DNA content $(1.0 \%$ - $8.0 \%)$ as compared with non-irradiated plants (control). The variants showing lateness in flowering showed moderate changes in DNA content as compared to short stature variants $(0.8 \%-2.7 \%)$. Bunch abnormalities variants showed slight to moderate changes in DNA content as compared to control plants with DNA content differences ranging from $0.1 \%$ to $1.1 \%$.

The Mann-Whitney Test (Non-parametric and Distribution-Free Statistics) showed that there were no significant differences between the three characters in 
DNA content at $(0.005>\mathrm{p}>0.001)$. On the other hand, phenotypic variation due to mutagenesis is reflected in the DNA content of plants. Table 3 demonstrates that the degree of variation in DNA content values increased as the dose of gamma-irradiation was increased from $20 \mathrm{~Gy}$ through to $60 \mathrm{~Gy}$. The DNA content at 20 \& 30 Gy treatments differed from that of nonirradiated plants by $2.5 \%$ and $2.8 \%$, respectively. Whereas, $40 \mathrm{~Gy}$ and $60 \mathrm{~Gy}$-variants showed more changes (4.7\% and 4.5\% for 40 Gy \& 60 Gy treatments, respectively) (Table 3).

Table 2. Summary and statistical analysis of results obtained by flow cytometric estimation of nuclear DNA content in Musa

\begin{tabular}{lcccc}
\hline \multicolumn{1}{c}{ Variants } & $\begin{array}{c}\text { 2C DNA } \\
\text { content value } \\
(\mathrm{pg})\end{array}$ & $\pm \mathrm{SE}$ & $\begin{array}{c}\text { 1C DNA content } \\
(\mathrm{Mbp})\end{array}$ & $\begin{array}{c}\text { Differences }(\%) \\
\text { from control }\end{array}$ \\
\hline- Control & 1.875 & 0.014 & 904.6 & - \\
- Dwarf \& stunted growth & 1.9595 & 0.029 & 945.5 & $40.9(4.5 \%)$ \\
$\begin{array}{l}\text { - Late flowering } \\
\text { Abnormalities in bunch } \\
\text { character }\end{array}$ & 1.9024 & 0.022 & 917.9 & $13.3(1.5 \%)$ \\
\hline
\end{tabular}

* $1 \mathrm{Pg}=965 \mathrm{Mbp}$ (Bennett and Smith 1976).

Table 3. Summary and statistical analysis of results obtained by flow cytometric estimation of nuclear DNA content in Musa (Pisang Berangan, AAA) at different Gamma-doses.

\begin{tabular}{ccccc}
\hline \hline $\begin{array}{c}\text { Irradiation doses } \\
(\mathrm{Gy})\end{array}$ & $\begin{array}{c}\text { 2C DNA } \\
\text { content values } \\
(\mathrm{pg})\end{array}$ & $\pm \mathrm{SE}$ & $\begin{array}{c}\text { 1C DNA content } \\
\text { values } \\
(\mathrm{Mbp})\end{array}$ & $\begin{array}{c}\text { Differences }(\%) \text { from } \\
\text { control }\end{array}$ \\
\hline 0 (Control) & 1.8460 & 0.0018 & 890.7 & - \\
20 & 1.8913 & 0.0045 & 912.6 & $21.9(2.5 \%)$ \\
30 & 1.8980 & 0.0050 & 915.8 & $25.1(2.8 \%)$ \\
40 & 1.9327 & 0.0054 & 932.5 & $41.8(4.7 \%)$ \\
60 & 1.9296 & 0.0093 & 931.03 & $40.3(4.5 \%)$ \\
\hline
\end{tabular}

* $1 \mathrm{Pg}=965 \mathrm{Mbp}$ (Bennett and Smith 1976).

S.E for the Total $=3.232 \mathrm{E}-03$ 
Ploidy analysis and DNA content of banana mutant — Abdelgadir Rayis Shadia et al.

The relationship between short stature variants and high doses of irradiation was apparent. The majority of short stature or stunted growth variants were selected from 40 \& 60 Gy treatments. (Table 1). Other variants such as late maturity and bunch-abnormalities also showed decrease in genomic DNA content ranging from $2 \%$ to $4 \%$, suggesting that the variation in DNA content has phenotypic effects via its influence on cell size and mitotic cycle time (Van Harten 1998).

The results indicate that gamma ray has a direct effect at the DNA level of Pisang Berangan and that this variation can be effectively measured using the flow cytometric technique. The high range of phenotypic changes observed at $40 \mathrm{~Gy}$ and $60 \mathrm{~Gy}$ treatments might be due to broken segments lost or translocated or may originate from deletions in the nucleotide sequences in structural genes, changes in the promoter sequences, deletions of the introns, regulating gene and repressers, which may either cause frame shift mutations or lead to the production of modified gene expression. It is estimated that at least $90 \%$ of the radiationinduced mutations refers to deletions (Van Harten 1998). In addition, duplication may occur resulting in an increase in the amount of DNA content control (insertion). This phenomenon might be due to jumping genes or double replication in DNA (copied twice) induced by irradiation.

This technique has immediate application for selection of potentially useful mutants for Pisang Berangan breeding programme. It may be expected that the number of practical applications will increase and plant breeders will even more extensively use flow cytometry.

\section{ACKNOWLEDGEMENTS}

I would like to express my gratitude to the Malaysian Institute For Nuclear Technology Research (MINT) and Mr. Azhar Mohamad for the facilities and assistance throughout the duration of experiment. Also to Prof. T. K. Mukheraji (Institute of Biological Science) for his advice in statistical analysis.

\section{REFERENCES}

Dolezel, J. P. Binarova and S. Luretti. 1989. Analysis of Nuclear DNA Content in Plant Cells by Flow Cytometry. Bio. Plant. 31: 133-120.

Dolezel, J., M.Dolezelova and F. Novak. 1994. Nuclear DNA amount in diploid bananas (Musa accuminata and M.balbisiana). Biol. Plant. 36: 351-357.

Dolezel, J. M. A. Lysak, I. Van Den Houwe, M. Dolezelova, N. Roux. 1997. Use of flow cytometry for rapid determination in Musa species, - INFOMUSA. 6: 6-9.

Dolezel, J., 1991. Flow cytometric analysis of nuclear DNA content in higher plants - Phytochem. Analysis 2: $143-$ 154. 
Dolezel, J. 1995. Application of Karyology and Cytometry in mutation breeding of African plantain in vitro. FAO/IAEA Research Co-ordination Meeting on: Cellular Biology and Biotechnology Including Mutation Techniques for Creation of New useful Banana Genotypes. FAO/IAEA, 1995, p. 13-22.

Gailbraith, D. W., K. R. Harkins, J. M. Maddox, N. M. Ayres, D. P. Sharma and E. Firoozabady. 1983. Rapid Flow Cytometric Analysis of the Cell Cycle in Intact Plant Tissues. Science, 220: 1049-1051.

Ho, Y. W. and Y. P. Tan. 1990. Performance of tissue cultured bananas. Perak Planters Annual Report 1990: 6775.

INIBAP, 1992. Banana and Plantain- Food for thought. In: Annual Report INIBAP, Montpellier, France.

Kaemmer, D., D. Fisher, R. L. Jarret, F. C. Baurens, A. Grapin, D. Dambier, J. L. Noyer, C. Lanaud, G. Kahl and P. J. L. Lagoda 1997. Molecular breeding in the Genus Musa: A strong Case for STMS Marker Technology. Euphytica 96: 46-63.

Larkin, P. J.. 1998. Induced Mutation for Crop Improvement. In: Somaclonal Variation and Induced Mutations in Crop Improvement, (eds) by Jain, S. M.; D. S. Brar and B. S. Ahloowalia (1998). p 3 - 13.

Mak C., Y. W. Ho, Y. P. Tan and R. Ibrahim. 1995. Novaria- a new banana Mutant induced by gamma irradiation. Infomusa 4: 1.

Novak, F.J., 1992. Musa (banana and plantains) In: Biotechnology of Perennial Fruit Crops, p.449-488 (eds F.A. Hammerschlag and R.E Litz) Wallingford: C.A.B. International.

Ortiz, R. and D. Vuylsteke. 1996. Recent advance in Musa genetics, breeding and biotechnology. Plant Breeding Abst. 1996,66: 1355-1363.

Siti Hawa, J. 1998. Commercial Exploitation of the Banana Diversity in Malaysia. Proceedings of the First National Banana Seminar (Genting Highland) 23-25 Nov. 1998.

Tiersch, T. R., R. W. Chandler, S. S. Watchel and S. Elias. 1989. Reference Standards for Flow Cytometry and Application in Comparative Studies of Nuclear DNA Content. Cytometry, 10: 706-710.

Van Harten, A. M., 1998. Mutation breeding. Theory and Practical Applications, Cambridge Univ., p. 163-203.

Vinderlov L. L., I. J. Christensen and N. I. Nissen. 1983. Standardization of high-resolution flow cytometric DNA analysis by the simultaneous use of chicken and trout red blood cells as internal reference standards. Cytometry 3: 328-331.

Vuylsteke, D. R., 1998. Field Performance of Banana Micropropagules and Somaclones. In: Somaclonal Variation and Induced Mutation in Crop Improvement (eds) by S. M. Jain; D. S. Brar; and B. S. Ahloowalia) p. 219-231.

Wiame I., R. Swennen, L. Sagi, Plas-LHW-van-der, J. J. Dons, J. Vanderleyden and M-de Loosse. 2000. PCRbased cloning of candidate disease resistance gene from banana (Musa acuminata). In: Proceedings of the xxv International Horticultural Congress. Part II. Application of Biotechnology \& Molecular Biology and breeding, genome analysis, Brussels, Belgium, 2-7 August, 1998. Acta-Horticulturae, 2000. 521,51-57. 